University of Windsor

Scholarship at UWindsor

1998

\title{
Toward achieving a focal point for sport management: $A$ binocular perspective
}

Robert Boucher

University of Windsor

Follow this and additional works at: https://scholar.uwindsor.ca/humankineticspub

Part of the Kinesiology Commons

\section{Recommended Citation}

Boucher, Robert. (1998). Toward achieving a focal point for sport management: A binocular perspective. Journal of Sport Management, 12 (1), 76-85.

https://scholar.uwindsor.ca/humankineticspub/3

This Article is brought to you for free and open access by the Faculty of Human Kinetics at Scholarship at UWindsor. It has been accepted for inclusion in Human Kinetics Publications by an authorized administrator of Scholarship at UWindsor. For more information, please contact scholarship@uwindsor.ca. 


\title{
Toward Achieving a Focal Point for Sport Management: A Binocular Perspective
}

\author{
Robert L. Boucher \\ University of Windsor
}

If I might speak for those who have had the privilege of giving this lecture before me, I can say that this is truly a humbling experience. To illustrate exactly how I feel this evening, I would like to relate a true story about one of my all-time favorite historical figures-Winston Churchill:

In the summer of 1941, Sergeant James Allen Ward was awarded the Victoria Cross for climbing onto the wing of his Wellington bomber 13,000 feet above the Zuider Zee in Holland to extinguish a fire in the starboard engine. Secured only by a rope around his waist, he managed not only to smother the fire but also to return along the wing to the aircraft's cabin. Churchill, an admirer as well as a performer of swashbuckling exploits, summoned the shy New Zealander to 10 Downing Street (for our American friends that's like the British White House). Ward was struck dumb with awe in Churchill's presence and was unable to answer the Prime Minister's simplest questions. Churchill surveyed the unhappy hero with some compassion. "You must feel very humble and awkward in my presence," said Churchill. "Yes sir," stammered the young flyer. "Then you can imagine how humble and awkward I feel in yours," said Churchill. (Fadiman, 1985, pp. 122-23)

I use this story certainly not to compare myself to this great British parliamentarian and wartime leader but to express the sense of humility I have in addressing this very special gathering.

Perhaps the most daunting aspect of accepting an invitation to give this address is the fact that it is named in honor of Earle Zeigler. What a unique individual he is! How fitting it is that this organization honors his lifetime of scholarship and professional contributions with this lecture. The breadth and distinction of his accomplishments are, and will remain, uniquely impressive. Earle's values, dedication, lifestyle, achievements, and humaneness reflect the ideals of excellence to which all of us should aspire. So you now may be able to appreciate the dilemma one faces when preparing for this kind of lecture. On the one hand, expectations are indeed high! The burden of being profound in light of the articulate and insightful offerings of my predecessors is truly daunting. Russell Baker, a columnist for the New York Times, once said that writing such a speech involves "sitting in

Robert L. Boucher is with the School of Human Kinetics at the University of Windsor, Windsor, ON N9B 3P4. 
front of a blank piece of paper until blood appears on your forehead" (Ailes, 1985). I can attest that this actually happens ... While humbled by the honor and daunted by the prospects of not measuring up to my predecessors, I am nonetheless challenged at the opportunity to present to a "captured, well-fed" audience my limited vision of our field, coupled, of course, with some of my personal biases.

In 1991, in Tampere, Finland, this author had the pleasure of addressing the General Assembly of the World Congress on Sport for All. At that time I made the following observation:

The 1990s finds the administration of sport, athletics, and recreation in a state of veritable transition. With the proliferation of sport opportunities and the commercialization of many forms of sport during the $1970 \mathrm{~s}$ and $1980 \mathrm{~s}$, notions of how to manage a sport organization efficiently and effectively have undergone marked and profound changes. (Boucher, 1991, p. 517)

In the five years that have passed since my trip to Finland, it is my contention that the thrust of these comments still rings true. There is no question that the field of Sport Management has grown and developed at a rapid pace, particularly over the past decade. Concurrent with this growth have been advancements made by professional and academic associations, formed to further the needs of a variety of individuals who are affiliated with Sport Management. The North American Society for Sport Management, in particular, has been noteworthy in this regard and is known throughout the world as the model for other national and international associations with similar mandates.

We also have witnessed undergraduate and graduate programs increasing across North America to the degree where accreditation has become a matter of concern to both NASSM and the National Association for Sport and Physical Education. It can be safely said that we have emerged from a decade of unfettered growth, increased recognition, and, in some people's opinion, academic/professional respectability. In short, we are in the midst of a prosperous time for our field even though higher education, particularly in Canada, is under severe financial and structural pressures. Even though I am generally optimistic about the future of Sport Management and genuinely pleased with the developments of our field over the past few years, I feel it prudent to stop and reassess the direction we are taking.

The famous sport philosopher, Yogi Berra is said to have made the comment, "If you come to a fork in the road, take it!" In my humble opinion we have inadvertently followed Yogi's advice. Somewhere along "our path of progress" we came to a fork in the road and we took it! The only problem now is that we are on different paths, which are in some cases not even parallel, and will become more divergent the greater the time we travel on them. Having said this, I fully recognize that differences of opinion are healthy and that it is not necessary or required that everyone in our field act in a doctrinaire fashion holding exactly the same values and beliefs. What I am suggesting is that from time to time, and now is particularly appropriate, we make some effort to refocus what we are doing in order that the next 10 years of progress can be as satisfying and meaningful as the first 10 years.

While there are numerous areas of "fuzziness" that I could present to you this evening, in fairness to a very polite audience I will describe only two. Then, I will potentially strain the limits of my credibility by offering what I believe could be a focal point of our research and our curricula for years to come. At the risk of 
overextending Yogi's previous analogy, it is my contention that establishing a focal point would eliminate the blurred vision we sometimes experience when we come to "forks in the road."

\section{Sport Management: What's In A Name?}

It has only been in the last three decades that Sport Management has attained an identity and a distinctiveness that has set it apart from its other siblings in the human movement field. While most of our Sport Management programs have evolved from traditional physical education programs, few bear any resemblance to these teacher preparation programs that were so heavily subscribed in the $1960 \mathrm{~s}$ and 1970s. However, as other authors too numerous to mention, have cautioned, "The first pillar for the Sport Management profession should be built on the recognition that the focus be on sport!" The emphasis of curricular offerings and, in fact, the research done at this time still resided with our physical education background, and a recognizable "business orientation" was noticeably lacking. One has only to peruse the $\mathrm{Org}$ and $\mathrm{Ad}$ textbooks of this era to confirm this observation. From these earlier times, Whitson and MacIntosh (1990) note the development of Sport Management in Canadian universities followed directly from the commitment of Canadian governments to fund a sport system focused on high performance. The development of programs in the United States followed a somewhat different pattern as outlined by Hardy (1987). In Canada, because federal dollars were being spent, there was considerable pressure on national and provincial sport organizations to professionalize their financial administration and to foster the development of managerial competence, particularly in the areas of planning and policy making (Slack \& Hinings, 1987). Speaking specifically about Canada, Whitson and MacIntosh note that

technical and administrative professionals, most of whom have graduate or undergraduate degrees in either kinesiology/sport sciences or sport administration, have effectively taken over the role once played by the volunteer community in the making and implementation of sport policy. (1990, p. 40)

This quest for a strong business orientation is well-documented and some of our finest scholars have subscribed to the notion that if our field is to improve, we must go the way of commerce and business.

Consider the following quotations:

Sport is business. It is bought and sold like any other service or commodity. The symbolic relationship between television and sport has spurred the financial growth of both. (Zakrajsek, 1993, p. 2)

Sport, as many commentators have noted, is big business and big business is heavily involved in sport. (Slack, 1996, p. 98)

Further, it has been suggested by Parkhouse (1996) that the term Sport Management may, in fact, be misleading and "Sport Business" may be, in fact, a more accurate descriptor of our field. There is, of course, a great deal of evidence that the lexicon of business finance and marketing is now firmly rooted in the working cultures of many of our sport organizations.

While fully recognizing the current state of affairs, one is left to wonder why the discourse of sport management has so little to do with sport and so much to do 
with the systematic marketing and production of the sporting performance (Whitson \& MacIntosh, 1990). Regrettably, we may have shifted our balance off center to the degree that we have a preoccupation with the structural and organizational aspects of sport at the expense of the experiential, social, and philosophical discourses that have been part of our earliest connections with sport. This condition is akin to one described by Boileau in 1982 as sportism. To illustrate the degree to which we have been swayed, I draw your attention to a presentation given by Dennis O'Malley, the president and owner of Halo Distributing at the 1994 World Sports Management International Conference in Atlanta. The title of Mr. O'Malley's presentation was "New Markets for the Sports Industry: Beer, Sports, and Local Communities-Do They Mix?" The thrust of his talk, of course, was that for beer companies, a huge target audience exists through sports due to its "leisure components" (O'Malley, 1994).

Call me naive, but is it possible that today's promoters of commercialism in sport have become intoxicated by sponsorship revenues? One is left with the question: Is it right for a sport manager only to be a conduit by which a sponsor can achieve greater market penetration? My contention is simply that in our quest for legitimation, we may have sold our collective souls to the interests of big business. It can be argued that much of what comprises the Sport Management domain is not related to business and producing entertainment for profit. In fact, a large percentage of sport enterprises in the global community are of an amateur nature where the motives of participants, spectators, and administrators are of a more altruistic nature. Perhaps Chelladurai's (1992) observation that there are really, in fact, two fields, that of management of human services in sport and management of entertainment services through sport, is entirely accurate. In any event, the need to return to a balance in orientation and to refocus has never been more pressing.

\section{The Old "Bridging the Gap" Activity}

I recognize that not all of you will share my vision of the future nor my cursory analysis of the present state of affairs in our field. I fully recognize that I am attempting to satisfy at least two different audiences with somewhat incompatible orientations. The applied nature of Sport Management leads many in this audience to judge what they hear and what they read by the degree to which it can be applied in a real-life setting. These individuals deal with the current challenges of their jobs and do not have the luxury of waiting for the academics among us to resolve our theoretical disputes and arrive at some definitive answers about how the management of sport enterprises might be improved. One criticism posed by this group is that Sport Management research has been focused for the most part on narrow esoteric questions that are of interest only to other scholars who publish in the same journals. The thrust for doing research with a theoretical underpinning was first articulated by Spaeth in 1968. Since that time, numerous authors have reinforced the notion that Sport Management will be improved and enhanced as an academic field only through research. A few years later in 1972, Bob Morford wrote a very insightful article for Quest entitled, "Toward A Profession, Not a Craft." While written with physical educators in mind, Morford's stinging criticisms had great impact on those who would go on to teach and research in the newer subdiscipline of Sport Management. While most of Morford's article debates whether physical education is a discipline or a profession, he has this to say about the place of research: 
My few years in the physical education profession have brought me to the realization that we are primarily a group of doers with little or no theoretical rationale for what we do. The issue here centers around the absence of any real concern for the disciplinary or theoretical framework to support the profession. (Morford, 1972, p. 88)

More recently, and in similar fashion, there are several authors who have written that the salvation of Sport Management lies in the establishing of a distinct body of knowledge based on sound research. Olafson (1995), Parks (1992), Slack (1996), Paton (1987), and Parkhouse et al. (1982) have been noteworthy in this regard over the past decade. There are, of course, others who have consistently stressed the importance of applying research results, and Parks (1992) and Weese (1995) have been particularly persuasive on this point.

So where does this leave us? Is the gap between theory and practice so great that it cannot be bridged? My feeling is that a true blending of the theoretical and practical concerns is virtually impossible the way we are going at the present time. Attempting to bring the two components together has meant overintellectualizing the real world environment and watering down research to the degree that only "action research," which provides real answers to real problems, is appropriate.

I believe the answer lies in the separate consideration of our research concerns from those of our curriculum. It is my personal feeling that the chasm currently existing between "Theory" and "Practice" can be reduced if we make adjustments in focus with our research and our teaching. At the present time, some of our research suffers from problems of relevancy. In addition, our curriculum is overly dependent on the experiential components such as internships and field work. In short, our curriculum needs to be more theoretical and our research needs to be more practical.

It can be said that studying Sport Management is akin to studying a truck at rest and then drawing inferences about how it operates when it is on the road. This, of course, creates difficulties for those among us who design course content and pose research questions. It seems that we have succumbed somewhat to the notion that internships and fieldwork will be our curricular salvation. Thus, our graduates usually have many and varied real world, hands-on, practical experiences when they graduate. I have to be careful not to denigrate this element of our undergraduate preparation as the evidence supporting an experiential component is persuasive. However, we definitely need to spend more time in our courses discussing, debating, and resolving some of the fundamental ethical and social problems involving the management of sport enterprises in our society. If potential managers are not prodded to examine their own values and to grapple with the ethical consequences of certain managerial practices while at university, it is highly unlikely they will attend to these concerns once in the job market.

In the extremely insightful 26th Amy Homan's address of the National Association for Physical Education in Higher Education, Janet Harris had this to say, "There is only occasional recognition of the importance of critical/reflective competencies for sport managers by faculty members in this subdiscipline itself" (p. 400).

With respect to our research, the need for relevance is indeed acute. Parks and Bartley, in a recent 1996 article in JSM, make several salient points regarding the status of sport management scholarship, not the least of which is their observation that in this state of transition, an emphasis on scholarly activity is replacing the traditional emphasis on service (Parks \& Bartley, 1996). However, Weese (1995) 
warns us that our research must not be viewed as self-serving and must be judged by whether it makes a difference by managers in real world situations. One of our difficulties, of course, is the dilemma faced by researchers in selecting research problems. Pure research of a scientific nature is more valued by the academy, hence, more prestige and enhanced reputations will follow. Action research of a contract nature is more meaningful to sport organizations but, because of its very nature, is less generalizable and therefore has less credibility in academic circles. The first brand of research leads to academic reputation, tenure, promotion, and all the trappings of recognized scholarship. The second brand, of course, leads to contract income, possible consulting work, and closer ties to the actual sport enterprise. Perhaps the solution lies in what MacLean (1996) describes as "appreciative inquiry."

Originally conceptualized as an alternative to action research, appreciative inquiry does not focus on the solution to problems. It is fundamentally an approach to organizational analysis that is uniquely intended to discover, to understand, and to foster organizational learning and innovation. As Gotches and Leidema (1995) indicate, the aim of this brand of research is to generate new knowledge that expands "the realm of the possible" and helps the members of an organization to envision a collectively desired future and to design improved organizational systems. Action research focuses on problems and problem-solving, whereas appreciative inquiry focuses on what's going well to further a more provocative and positive future. This may lead to solutions that address some of the concerns of multiculturalism and diversity brought to our attention by Joy DeSensi in her 1993 Zeigler address. It is perhaps this renewal in a normative approach that deals with "what ought to be" rather than "what is" that captures my imagination.

\section{In Search of a Focal Point}

So where does this leave us when we attempt to find a focal point for this area of Sport Management? As a "practicing manager" for 22 of the last 25 years, my experiences can be distilled to two observations:

1. All problems are people problems.

2. Sound decision-making solves problems.

I am fully aware of the numerous components of accredited curricula with courses in sport marketing, sport and the law, facility management, sport and government, and so on. We have done a very thorough job of designating the various components of degree programs in our field. The NASPE/NASSM joint project on accreditation has done us proud by clearly articulating what are the minimal and desirable curricular experiences for undergraduate and graduate students in our field. However, we must not become afflicted by a condition that I would describe as "Accreditation Complacency." This, of course, is characterized by a professional smugness brought on when one's program is certified and thus all exiting graduates are presumed to have the requisite skills and competencies required to "manage" in the real world of sport. Providing the best possible curricular experience is important and should not be dismissed lightly. However, a true measure of whether graduates are truly prepared is not the courses listed on their transcripts but whether they have been educated to think intelligently and make decisions about issues they will face in the dynamic world of managing a sport enterprise. 
Referring back to our brief references to Sport Management and the "business bottom line," we presume our graduates will be able to turn a profit with the variety of sport enterprises that they will market and promote. We know they will be able to market these properties, but will they be able to manage them? The current emphasis on marketing in our field presupposes that getting the product to market is the foundational activity of Sport Management. The day-to-day activities of such managers, however, reveals the personnel matters, budget concerns, strategic planning, and a host of other activities are of equal importance. Regrettably, there is evidence to suggest that our graduates are less prepared to make the myriad of ethical, social, and philosophical decisions that involve the long-term viability of a sport enterprise.

Is there a solution to this? My crude analysis of our situation is that we are not spending sufficient time in our research and course offerings on the fundamental and irrefutable actions by sport managers that actually make a difference. What I am referring to is decision-making! As Vroom stated so appropriately in 1974,

All managers are decision-makers. Furthermore, their effectiveness as managers is largely reflected in their "track record" in making the "right decisions." These "right decisions," in turn, largely depend on whether or not the manager has utilized the right person or persons in the right ways in helping solve the problem. (p. 68)

This notion is, of course, not new to the field of management. The worldrenowned writer and researcher Herbert Simon in the 1940s was interested to know how decisions were made and how they might be made more effectively. The thrust of his writing was "management is decision-making" (Pugh \& Hickson, 1989). Other notable proponents of decision-making as the essence of management were James March, Charles Lindblom, Arnold Tannenbaum, and Victor Vroom.

Referring specifically to sport organizations, Daniel (1974) stated that "decision-making is like the nervous system of a complex organism" (p. 47). While in some quarters, management theorists have abandoned this area of research, there has been a continuing school of thought that maintains "that it is the analysis of decision-making which is the key to understanding organizational management processes" (Pugh \& Hickson, 1989, p. 135). And this, of course, is what I contend binds all of our various components together. Consider, for example, a typical day in the life of a sport manager. It is not inconceivable that he or she will do the following:

- Approve a marketing plan

- Consult on a legal matter

- Interview a job prospect

- Chair a disciplinary hearing

- Meet with a prospective sponsor

- Draft a facility use policy

This list, of course, could go on and, from my experience over the last 11 years, the above activities would probably take you to noon on a given day. ... In any event, the common element in all these managerial functions is decision-making. Referring to the previous activities, there will be marketing decisions, legal decisions, planning decisions, and so on. It has occurred to me that we spend a 
great deal of time in our courses and our research dealing with the content of these subject areas, but precious little time is devoted to how decisions are actually made regarding their disposition. There has been a widely subscribed to misconception that the more you know about something, the better decisions you will make. While it is true that having appropriate and timely information can lead to more informed decision-making, the process is certainly not that simple.

Another common misconception about decision-making is that when intelligent individuals use all the information at hand, rational decisions will be the result. The research that refutes this notion is staggering, yet few courses and little research in our field is devoted to shedding light on this area. Consider, for example, two incidents of which you will be familiar that debunk most rational decisionmaking models. The famous Bay of Pigs Invasion during the Kennedy Administration is described by Brunsson (1982) as being a classic example of irrational decision-making. Investigations revealed that in sessions leading up to the invasion, federal bureaucrats repressed large amounts of disturbing information and false impressions of unanimity were built up among the decision-makers, causing them to take unjustified risks of immense proportions.

Another classic example in faulty decision-making surrounds the Challenger space shuttle tragedy. Suters (1992) reports that assumptions were made about the safety of the launch which were not disproved until after the shuttle had exploded. Former Secretary of State William Rogers, the chairman of the committee investigating the Challenger disaster, repeatedly stated in his report that there were flaws in the decision-making process.

But what about sport? Are there cases of faulty decision-making that attracts our attention as the Bay of Pigs and Challenger examples? While it has been 10 years since the scandal of Ben Johnson at the Seoul Olympics, the incident is still fresh in the minds of Canadians and others who value sport in its purest form. A Commission of Inquiry, chaired by the Honorable Charles Dubin, spent the better part of two years uncovering the use of banned substances to increase athletic performance. In the 638-page report, Dubin (1990) chronicles a litany of "poor decisions" by government bureaucrats, volunteer board members, professional coaches and, of course, athletes. One does not have to spend much time reviewing the sordid details of drugs and sport to reveal that decisions made by those in managerial positions dictate the course of events. If the Canadian Government had not placed so much stock in the Olympic medals and the Canadian Track and Field Association had not turned a blind eye to obvious doping practices, the history of Canadian international sport would not be as it is written today.

I have used a Canadian case of world renown to illustrate the consequences of decision-making in the sport context. Other examples such as soccer hooliganism, exploitation of the college athlete, sport betting, and violence in sport might also have been appropriate to make the point that a series of poor decisions leads to our current state of affairs in the global sport arena.

At this juncture, it is probably warranted that remedies be proposed rather than to relate any more tales of tragedy and scandal. If those of us in the field of Sport Management were to give greater credence to "decision-making" in our curricula and our research, we could do much to provide a focal point for all of our various interests and concerns. Remember the aim is to prepare potential managers and assist practicing managers in making better decisions about sport. With respect to the parameters of this area of decision-making, the depth and breadth of 
the subject matter is inexhaustible. Potential sport managers could learn about heuristics and their affect on rational decision-making. They could study what Brockner and Rubin (1985) call the "entrapment syndrome" and the effects of sunk costs as identified by Ailes and Blumer (1985). Managers can learn of the relationship of values to decision-making and how this subconsciously influences personnel decisions and those with controversial overtones. Relying on authors such as Brunsson (1982), and Tallman and Gray (1990), the perceptual and intellectual activities involved when making choices between alternatives can be explored. Managers need to know the relationships between information and ideology as presented by Cummings (1983) as they relate to nonstrategic decisions.

The inherent appeal of this proposition is that decision-making cuts across all elements of our various curricula and our research. Irrational decisions impede and retard the implementation of the most sophisticated plans. Clearly, decisionmaking may be viewed as the weak link in the Sport Management chain.

In closing, I would like to point out to you that in terms of a philosophical disposition, I have been described as a realist who suffers occasional attacks of pragmatism. However, this evening for a short period of time, you have allowed me to reveal my heretofore hidden idealist tendencies. This was such a rare occurrence for me, I had to look up idealism. This is what I found: "An idealist is one who, on noticing that a rose smells better than a cabbage, concludes that it will also make better soup" (H.L. Mencken).

In hopes that we can all make better soup in the future, I thank you for your attention.

\section{References}

Ailes, R. (1985). Persuasive speaking: Esquire success series (Videocassette recording). New York: Esquire-Serendipity Associates.

Ailes, H.R., \& Blumer, C. (1985). The psychology of sunk cost. Organizational Behavior and Human Decision Processes, 35, 124-140.

Boileau, R. (1982). Rôle et statu du professionel de l'activité physique. In L'education Physique: Ou va La Profession? Montreal, PQ: Bellarniun-Desport.

Boucher, R.L. (1991). Enlightened management of sport in the 1990s: A review of selected theories and trends. In Sport for all (pp. 517-526). Amsterdam: Elsevier Science Publishers.

Brockner, J., \& Rubin, J.Z. (1985). Entrapment in escalating conflicts. New York: SpringerVerlag.

Brunsson, H. (1982). The irrationality of action and action rationality: Decisions, ideologies, and organizational actions. The Journal of Management Studies, 19, 29-43.

Chelladurai, P. (1992). Sport management: Opportunities and obstacles. Journal of Sport Management, 6, 215-219.

Cummings, L.L. (1983). The logics of management. Academy of Management Review, $\mathbf{8}$, $532-538$.

Daniel, J.V. (1974, March-April). The organization and decision-making. CAHPER Journal, $47-49$.

DeSensi, J.T. (1994). Multiculturalism as an issue in sport management. Journal of Sport Management, 8, 63-74.

Dubin, C.L. (1990). Commission of inquiry into the use of drugs and banned practices intended to increase athletic performance. Ottawa, ON: Canadian Government Publishing Centre. 
Fadiman, C. (1985). The little, brown book of anecdotes. Boston: Little, Brown, and Co.

Gotches, G., \& Leidema, J. (1995). An interview with David Cooperrider on appreciative inquiry and the future of organizational development. Organizational Dynamics, 13, $5-13$.

Hardy, S. (1987). Graduate curriculums in sport management: The need for a business orientation. Quest, 39, 207-216.

Harris, J.C. (1993). Using kinesiology: A comparison of applied veins in the subdisciplines. Quest, 45, 389-412.

MacLean, G.N. (1996). Action research in organizational development: Rest in peace? $\mathrm{Hu}$ man Resource Development Quarterly, 7, 1-3.

Morford, W.R. (1972). Toward a profession, not a craft. Quest, 28, 88-93.

O'Malley, D. (1994). New markets for the sports industry: Beer, sports, and local communities -Do they mix? Proceedings, World Sports Management Conference, Georgia Tech University.

Olafson, G.A. (1995). Sport management research: Ordered change. Journal of Sport Management, 9, 338-345.

Parkhouse, B.L. (Ed.) (1996). The management of sport: Its foundations and application (2nd ed.). St. Louis: Mosby-Year Books.

Parkhouse, B.L., Ulrich, D.O., \& Soucie, D. (1982). Research in sport management: A vital rung in this new corporate ladder. Quest, 34, 176-186.

Parks, J.B., \& Bartley, M.E. (1996). Sport management scholarship: A professoriate in transition? Journal of Sport Management, 10, 119-130.

Parks, J.B. (1992). Scholarship: The other "bottom line" in sport management. Journal of Sport Management, 6, 220-229.

Paton, G. (1987). Sport management research: What progress has been made? Journal of Sport Management, 1, 25-31.

Pugh, D.S., \& Hickson, D.J. (1989). Writers on organizations. Newbury Park, CA: Sage.

Slack, T. (1996). From the locker room to the board room: Changing the domain of sport management. Journal of Sport Management, 10, 97-105.

Slack, T., \& Hinings, R. (1987). Planning and organizational change: A conceptual framework for the analysis of amateur sport organizations. Canadian Journal of Applied Sport Sciences, 12, 185-193.

Spaeth, M.J. (1967). An analysis of administrative research in physical education and athletics in relation to a research paradigm. Unpublished doctoral dissertation, University of Illinois, Urbana-Champaign.

Staw, B.M. (1981). The escalation of commitment to a course of action. Academy of Management Review, 6, 577-587.

Staw, B.M. (1976). Knee deep in the big muddy: A study of escalating commitment to a chosen course of action. Organizational Behavior and Human Performance, 16, 27-44.

Tallman, I., \& Gray, L. (1990). Choices, decisions, and problem-solving. Annual Review of Sociology, 16, 405-433.

Vroom, V.H. (1974). A new look at management decision-making. Organizational Dynamics, 5, 66-80.

Weese, W.J. (1995). If we're not serving practitioners, then we're not serving sport management. Journal of Sport Management, 9, 237-243.

Whitson, D.J., \& MacIntosh, D. (1990). The scientization of physical education: Discourses in performance. Quest, 42, 40-51.

Zakrajsek, D.B. (1993), Sport management: Random thoughts of one administrator. Journal of Sport Management, 7, 1-6. 